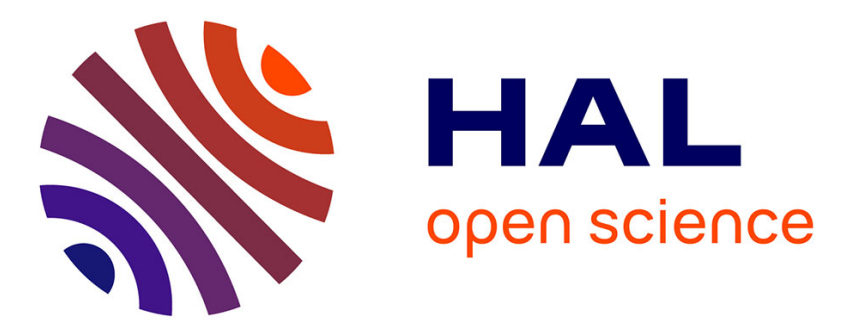

\title{
Transcriptional control of the glucocorticoid receptor: CpG islands, epigenetics and more.
}

\author{
Jonathan D. Turner, Simone R. Alt, Lei Cao, Sara Vernocchi, Slavena \\ Trifonova, Nadia Battello, Claude P. Muller
}

\section{- To cite this version:}

Jonathan D. Turner, Simone R. Alt, Lei Cao, Sara Vernocchi, Slavena Trifonova, et al.. Transcriptional control of the glucocorticoid receptor: CpG islands, epigenetics and more.. Biochemical Pharmacology, 2010, 80 (12), pp.1860. 10.1016/j.bcp.2010.06.037 . hal-00637161

\section{HAL Id: hal-00637161 \\ https://hal.science/hal-00637161}

Submitted on 31 Oct 2011

HAL is a multi-disciplinary open access archive for the deposit and dissemination of scientific research documents, whether they are published or not. The documents may come from teaching and research institutions in France or abroad, or from public or private research centers.
L'archive ouverte pluridisciplinaire HAL, est destinée au dépôt et à la diffusion de documents scientifiques de niveau recherche, publiés ou non, émanant des établissements d'enseignement et de recherche français ou étrangers, des laboratoires publics ou privés. 


\section{Accepted Manuscript}

Title: Transcriptional control of the glucocorticoid receptor:

$\mathrm{CpG}$ islands, epigenetics and more.

Authors: Jonathan D. Turner, Simone R. Alt, Lei Cao, Sara

Vernocchi, Slavena Trifonova, Nadia Battello, Claude P.

Muller

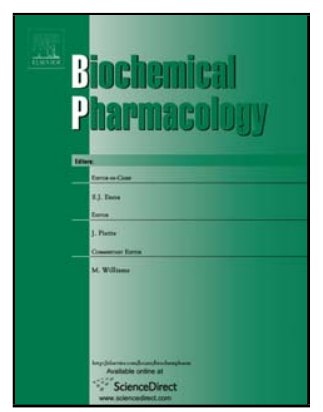

PII:

S0006-2952(10)00471-5

DOI:

doi:10.1016/j.bcp.2010.06.037

Reference:

BCP 10618

To appear in: $\quad B C P$

Received date: $\quad$ 4-5-2010

Revised date: $\quad 18-6-2010$

Accepted date: $\quad$ 21-6-2010

Please cite this article as: Turner JD, Alt SR, Cao L, Vernocchi S, Trifonova S, Battello N, Muller CP, Transcriptional control of the glucocorticoid receptor: CpG islands, epigenetics and more., Biochemical Pharmacology (2010), doi:10.1016/j.bcp.2010.06.037

This is a PDF file of an unedited manuscript that has been accepted for publication. As a service to our customers we are providing this early version of the manuscript. The manuscript will undergo copyediting, typesetting, and review of the resulting proof before it is published in its final form. Please note that during the production process errors may be discovered which could affect the content, and all legal disclaimers that apply to the journal pertain. 
GR Transcription

1 Transcriptional control of the glucocorticoid receptor: $\mathrm{CpG}$ islands, epigenetics and more.

3 Jonathan D. Turner ${ }^{1,2}$, Simone R. Alt ${ }^{1,2}$, Lei Cao ${ }^{1,2}$, Sara Vernocchi ${ }^{1,2}$, Slavena

4 Trifonova $^{1,2}$, Nadia Battello ${ }^{1}$, Claude P. Muller ${ }^{1,2}$

$6{ }^{1}$ Institute of Immunology, CRP-Santé / Laboratoire National de Santé, 20A rue Auguste

7 Lumière, L-1950, Luxembourg

$8{ }^{2}$ Department of Immunology, Graduate School of Psychobiology, University of

9 Trier, D-54290, Germany

10

13 Running title: GR transcription

16 Address for correspondence:

17 Claude P. Muller, Institute of Immunology, CRP-Santé/Laboratoire National de Santé,

18 20A rue Auguste Lumière, L-1950 Grand Duchy of Luxembourg.

19 Tel: +352 490604 Fax: +352 490686

20 Email: claude.muller@LNS.ETAT.LU 
GR Transcription

\section{Abstract}

2 The unique variability in the 5' region of the GR gene, with 9 alternative first exons and

313 splice variants plays a critical role in transcriptional control maintaining homeostasis

4 of the glucocorticoid receptor (GR). This 5'mRNA heterogeneity, common to all species

5 investigated, remains untranslated since the alternative first exons are spliced to exon 2

6 immediately upstream of the translation initiation codon. These alternative first exons are

7 located either immediately upstream of the coding exons in the $\mathrm{CpG}$ island (exons B-H

8 and $\mathrm{J}$ ), or further upstream (exons 1A and 1I). The mechanisms regulating the differential

9 usage of these first exons in different tissues and individuals, and the role of the 5'UTR

10 in the splicing of the coding exons are still poorly understood. Here we review some of

11 the mechanisms that have so far been identified. Data from our laboratory and others

12 have shown that the multiple first exons represent only a first layer of complexity

13 orchestrated probably by tissue-specific transcription factors. Modulation of alternative

14 first exon activity by epigenetic methylation of their promoters represents a second layer

15 of complexity at least partially controlled by perinatal programming. The alternative

16 promoter usage also appears to affect the 3 ' splicing generating the different GR coding

17 variants, GR $\alpha$, GR $\beta$, and GR-P. Aberrant GR levels are associated with stress-related

18 disorders such as depression, and affect social behaviour, mood, learning and memory.

19 Dissecting how tissue-specific GR levels are regulated, in particular in the brain, is a first

20 step to understand the significance of aberrant GR levels in disease and behaviour.

22 Keywords: Glucocorticoid receptor; Promoter; Methylation; Epigenetic variability;

23 alternative exon splicing 
GR Transcription

\section{Introduction}

2 Stress causes an increasing disease burden at least in Western societies. Economic losses

3 due to stress may be as high as 3-4\% of the European gross national product. In addition,

4 stress has detrimental effects on behaviour, mood, learning and memory that are difficult

5 to quantify. Glucocorticoids (GCs), the key stress mediators, exert profound effects on a

6 wide range of physiological and developmental processes that are crucial for the

7 adaptation to stress. Psychosocial stress has also been implicated in the development of

8 mental disorders, including schizophrenia, anxiety disorders, and depression.

9 GCs act via binding to two types of intracellular nuclear receptors, i.e. the glucocorticoid

10 receptor (GR) and the mineralocorticoid receptor (MR). Upon binding of GCs, these

11 receptors translocate to the nucleus where they regulate the activity of specific target

12 genes, in a cell-type specific manner, as transcription factors. This review focuses on the

13 classical GR, NR3C1. Numerous factors have been demonstrated to affect the

14 responsiveness to GC by regulating GR activity, such as GR co-activators and co-

15 repressors [1], GR splice-variants [2-4], and GR isoforms [5-7]. In addition, and perhaps

16 most important for GC responsiveness is the expression level of GR protein [8-11],

17 determined by the mRNA level.

18 In eukaryotic cells, gene expression is controlled by a variety of mechanisms, both at

19 transcriptional and translational levels, including chromatin condensation, transcription

20 initiation, DNA methylation, alternative RNA splicing, mRNA stability and others. The

21 GR is an ubiquitously expressed nuclear hormone receptor, however, levels of both

22 mRNA and protein vary widely between cell and tissue types. Over the last few years we

23 and others have contributed to the significant progress that has been made to unravel the 
GR Transcription

1 transcriptional mechanisms determining the tissue specific control of GR levels, that will

2 be reviewed here.

\section{Structure of the NR3C1 gene}

5 The human GR gene (OMIM + 138040; NR3C1) is located on chromosome 5q31-q32

6 [12] and contains 8 translated exons (2-9) and 9 untranslated alternative first exons. We

7 and others have shown that GR levels are under the transcriptional control of a complex

85 ' structure of the gene, containing the untranslated first exons important for differential

9 expression of the GR. All of the alternative first exons identified are located in one of the

10 two promoter regions: the proximal or the distal promoter region, located approximately

$115 \mathrm{~kb}$ and $30 \mathrm{~kb}$ upstream of the translation start site, respectively [13-18]. Alternative first

12 exons 1A, and 1I are under the control of promoters in the distal promoter region,

13 whereas the promoters of exons 1D, 1J, 1E, 1B, 1F, 1C (1C1-3), 1H (Fig. 1A) are located

14 in the proximal promoter region $[19,20]$. Exons $1 \mathrm{D}$ to $1 \mathrm{H}$ are found in an upstream $\mathrm{CpG}$

15 island with a high sequence homology between rats and humans.

16 The region- or tissue-specific usage of alternative first exons leading to different GR

17 mRNA transcripts [19, 20] (Fig. 1 B) provides a mechanism for the local fine-tuning of

18 GR levels. Since the ATG start codon lies only in the common exon 2, this 5'mRNA

19 heterogeneity remains untranslated, but is important for translational regulation [21].

20 Alternative mRNA transcript variants are generated by splicing of these alternative first

21 exons to a common acceptor site in the second exon of the GR. Exon 2 contains an in-

22 frame stop codon immediately upstream of the ATG start codon to ensure that this 5' 
GR Transcription

1 heterogeneity remains untranslated, and that the sequence and structure of the GR is not

2 affected.

3 The GR also has a variable 3' region. Unlike the 5' region, the 3' variability encodes

4 splice variants with different functions. The 3 main 3' splice variants of the GR are GR $\alpha$,

5 GR $\beta$, and GR-P (Fig. 1B). GR $\alpha$ and GR $\beta$ are generated by two alternatively spliced 3'

6 exons, $9 \alpha$ and $9 \beta$. GR-P lacks both exons 8 and 9 and is translated into a protein with a

7 truncated ligand binding domain (LBD) which is thought to enhance GR $\alpha$ activity. GR $\alpha$

8 is by far the most active form of the receptor, GR $\beta$ is thought to be a dominant negative

9 regulator of the receptor, and little is known about the function of GR-P.

\section{Alternative first exon usage and 3' splice variants}

12 The recent observation that transcription factors binding to pol II transcribed promoters

13 modulate alternative splicing, supports a physical and functional link between

14 transcription and splicing [22]. Several factors were identified that were critical for the

15 recruitment of a specific set of co-regulators to pol II transcribed gene promoters and the

16 production of a specific splice variants. The splice variant produced depends on the

17 structural organisation of the gene and the nature of the co-regulators involved [23]. A

18 link between transcription initiation sites and the resulting splice variant was suggested

19 since it was shown that promoters controlled alternative splicing also via the regulation of

20 pol II elongation rates or processivity. Slow pol II elongation paired with internal

21 elongation pauses favoured the inclusion of alternative exons governed by an exon

22 skipping mechanism, whereas high elongation rates of pol II, without internal pauses

23 favoured the exclusion of such exons. 
1 Many eukaryotic genes contain multiple promoters that are alternatively used for the

2 production of different protein isoforms, with important physiological consequences.

3 However, the GR with its variable 5' UTR, and alternative splicing in the 3' coding

4 region is unique. Little is known about the association between the promoter usage and

5 the resulting GR protein isoform. The 5' UTR has tight control over local GR expression

6 levels. There seems to be also a poorly understood statistical link between the 5'UTR and

7 3' splice variants produced. One of the first studies to address this question showed that

8 exon $1 \mathrm{~A} 3$, and to a lesser extend $1 \mathrm{~B}$ and $1 \mathrm{C}$ contribute most to the expression of GR- $\alpha$

9 isoform [24]. By comparing the most abundant exon 1 containing transcripts (1A, 1B 1C)

10 with GR $\alpha$, GR $\beta$, and GR-P containing transcripts in different tissues and cell lines,

11 Russcher et al. found a correlation between promoter usage and alternative splicing of the

12 GR gene [25]. More specifically they found that the expression of GR $\alpha$ is preferentially

13 regulated by promoter $1 \mathrm{C}$, whereas $1 \mathrm{~B}$ usage favours the expression of GR-P isoform. No

14 association was found with transcripts including exon $9 \beta$ or with those transcribed from

$151 \mathrm{~A}$, suggesting that GR $\beta$ splicing may be associated with one of the recently identified

16 exon 1 variants such as $1 \mathrm{D}$ to $1 \mathrm{~F}$ and $1 \mathrm{H}$ that were not included in the above study [25].

17 We also confirmed that in post-mortem brain tissues of patients with major depressive

18 disorder (MDD) altered promoter usage influenced the resulting $3^{\prime} \mathrm{GR}$ isoform, with a

19 negative correlation between GR-P expression and promoter 1B usage in all brain areas

20 of MDD patients but not in normal control brains. A negative correlation was also found

21 between the 1C promoter usage and GR-P expression in MDD brains. These results

22 suggest that the promoters $1 \mathrm{~B}$ or 1C do not play a significant role in GR-P expression in

$23 \mathrm{MDD}$, and that they were rather linked to other forms with lower expression [26]. Thus, 
GR Transcription

1 current data suggest a link between the two ends of the mRNA transcript, but there is no

2 consensus as to the nature of this link.

\section{Transcription factors and transcriptional control within the $\mathrm{CpG}$ island}

5 The hGR was initially described as a housekeeping or constitutively expressed gene with

6 promoters that contain multiple GC boxes and no TATA or TATA-like box [27]. A wide

7 variety of transcription factors have been identified that bind in the CpG island upstream

8 of the gene. The description of the transcription factors active within this region is

9 complicated by their tissue-specific usage. These transcription factors were not assigned

10 to the different exon 1 promoters since most of this work was performed before our

11 detailed description of the first exons in this region. The transcription factors so far

12 identified are summarised (Table 1) and their location within the $\mathrm{CpG}$ island shown in

13 Figure 1C. Initially, 11 DNAse 1 footprints representing unique transcription factor

14 binding sites were found in the $1 \mathrm{C}$ to $1 \mathrm{~F}$ region of the $\mathrm{CpG}$ island ( -3259 to -2522 from

15 the ATG start codon) including, one AP-2 and 5 Sp-1 binding sites were identified [28].

16 It was initially thought that the latter transcription factors played an essential role in the

17 basal expression of the hGR, although this is now less clear. Further studies identified

18 one of the footprints in promoter $1 \mathrm{C}$ as a binding site for the transcription factor Yin

19 Yang 1 [15]. YY1, expressed in a wide variety of mammalian cell types, is a zinc-finger

20 transcription factor that can act as an activator, a repressor, or an initiator of transcription

$21[17,29]$. The same authors also revealed three other YY1 sites and another Sp1 site,

22 initially assigned to promoter 1B. The later identification of promoter 1D suggested that 
1 these YY1 sites are probably associated with this promoter [30]. Similarly, the Sp1 sites

2 correspond to a region that was later identified as promoter $1 \mathrm{~J}[20]$.

3 Similarly, several transcription factors initially assigned to promoter $1 \mathrm{C}$ should be

4 reassigned to promoter 1F. AP-1, a transcription complex whose components are encoded

5 by c-fos and c-jun proto-oncogenes binds to the AP-1 site within the hGR promoter $1 \mathrm{~F}$

$6[14,31]$. This same region was also shown to bind $\mathrm{Ku} 70$ and $\mathrm{Ku} 80$ in a tissue-specific

7 manner [32]. Whilst most of the transcription factors identified upregulate GR

8 expression, GRF-1 (glucocorticoid receptor DNA binding factor 1) has been identified as

9 a repressor of GR transcription [33, 34]. At the 3 ' end of the rat $1_{7}$ promoter a NGFI-A

10 binding site was identified only 2 bp upstream of the transcription initiation site of this

11 exon [35]. Recently, the homologous human NGFI-A binding site, together with

12 numerous non-canonical NGFI-A sites were identified in promoter 1F of the hGR [36].

13 As a transcription factor, GR also auto-regulates its own CpG island promoters. Several

14 glucocorticoid response element (GRE) half-sites, acting in concert with c-Myb, and c-

15 Ets protein members have been identified in promoter 1D, 1E, 1F and 1C [37].

16 The currently known transcription factors provide only an incomplete picture of the

17 complex regulatory mechanisms. For instance, little is known about the proximal

18 elements in promoters $1 \mathrm{~B}$ and $1 \mathrm{H}$. Using an in silico phylogenetic footprinting technique

19 we were able to find the majority of the experimentally identified transcription factors,

20 and predicted a wide variety of factors that are conserved between many species [38].

21 These are interesting candidate regulators of GR expression that warrant further

22 investigations. 
GR Transcription

1 It has not yet been shown whether the transcription factors that bind immediately

2 upstream of exons D, E, F, H, and I, activate the expression of these exons. Only site 13,

3 one of 6 in the region immediately upstream of exon 1F (Fig. 1C), has been shown to

4 activate transcription of the downstream exon. Furthermore, the link between the

5 transcription factors previously identified, or predicted, and the transcription of the new

$6 \quad \mathrm{CpG}$ island first exons must be established.

8 Transcriptional control upstream of the CpG island: Exon $1 \mathrm{~A}$ and $1 \mathrm{I}$

9 Whilst the majority of the GR first exons and their promoters are located within the $\mathrm{CpG}$

10 island, exons $1 \mathrm{~A}$ and $1 \mathrm{I}$ map $25 \mathrm{~Kb}$ upstream of the $\mathrm{CpG}$ island and $32 \mathrm{~Kb}$ upstream of

11 the main GR ORF in the distal promoter region [16, 20]. Exon 1A has also been

12 identified in the mouse, and three possible homologues $1_{1}, 1_{2}$, and $1_{3}$ have been found in

13 the rat $[39,40]$. The human promoter $1 \mathrm{~A}$ generates 3 alternatively spliced transcripts,

14 1A1, 1A2 and 1A3 [16]. Expression of the 1A transcripts appears to be limited to the

15 immune system in both humans and rodents. The human $1 \mathrm{~A} 3$ transcript is widely

16 expressed in both acute lymphoblastic leukemia (ALL) cell lines and in children with this

17 malignancy [16, 20, 25, 41-43]. Similarly, exon 1I is used predominantly in T cells,

18 although it is also present in HeLa cells [20].

19 Promoter $1 \mathrm{~A}$ is regulated by the GR itself. The human 1A promoter contains a GC-

20 responsive cassette containing a non-canonical GRE adjacent to overlapping binding sites

21 for c-Myb and c-Ets protein family members. In the presence of c-Myb the ligand-bound

22 GR is recruited to the promoter and up-regulates 1A transcripts, while the interaction

23 with c-Ets family members leads to a repression of $1 \mathrm{~A}$ promoter activity $[18,44]$. This 
1 explains in part the opposite effects observed in different tissues: in most tissues GC

2 decreases GR expression, but in and certain T cells GCs increase GR expression. The

3 synergy between c-Ets and the GR has been shown to be responsible for the down

4 regulation of $1 \mathrm{~A} 3$ in the B lymphoblastoid cell line IM-9 after GC exposure. In contrast,

5 the presence of c-Myb in $\mathrm{T}$ cells increased the activity of promoter $1 \mathrm{~A}$ in human cell lines

6 such as the ALL T cell line CEM-C7. As a result of the higher level of total GR T cells

7 are more sensitive to GC induced apoptosis, and 1A3- transcripts were shown to be the

8 most GC responsive of all first exons investigated [16, 24]. Although 1A containing

9 transcripts correspond to only about $10 \%$ of all GR transcripts [42], their contribution to

10 the tissue-specific response to $\mathrm{GC}$ treatment was considered essential $[16,24]$. The

11 human promoter 1A also has a functional binding site for Interferon Regulatory Factors

12 (IRF-1 and IRF-2), however IFN $\gamma$ stimulation of CEM-C7 cells did not increase 1A

13 transcript levels, nor did it alter their susceptibility to GC-mediated apoptosis [45].

14 Thus the evidence suggests that $1 \mathrm{~A}$ transcript levels are critically involved in mechanisms

15 of therapeutic induction of apoptosis in ALL T cells. However, GC resistance in pediatric

16 T- and B- ALL cells obtained directly from patients did not correlate with either the basal

17 or the stimulated expression of the 1A-, 1B- or 1C- transcripts. The relation between GC

18 sensitivity and expression of GR transcripts may be complicated by the overlapping

19 effects such as multi drug resistance genes that prevent GC concentrations from building

20 up in the cells. In addition, ALL cells were shown to have an up-regulated GR expression

21 upon prednisolone treatment regardless of their phenotype or sensitivity to GC-induced

22 apoptosis [42]. 
1 In mice the presence of the membrane-bound GR was a better correlate of GC-induced

2 apoptosis than the intracellular GR level [46, 47]. Exon 1A was found to be highly

3 expressed in a T lymphoma cell line with elevated levels of membrane-bound GR and

4 enhanced sensitivity to GC-dependent cytotoxicity. 1A transcripts appear to contain all

5 the necessary information for both the synthesis and the subcellular trafficking of the

6 membrane GR, although the exact mechanism remains unknown [41]. It is interesting to

7 hypothesise that the initially presumed link between GC induced apoptosis and 1A

8 transcript levels is indirect, with $1 \mathrm{~A}$ transcripts producing membrane GR the true

9 correlate of GC sensitivity. Recently a similar membrane GR has been detected in human

10 cells, but its sequence is not known $[48,49]$. The membrane GR may eventually explain

11 the discrepancy between the in vivo and in vitro observations in ALL. It is interesting to

12 speculate that, as in the mouse, the different first exons determine the cellular fate of the

13 human GR.

14 Further sequence analysis of mouse exon $1 \mathrm{~A}$ found 5 small upstream-ORFs preceding the

15 major ORF of the GR. It has been shown that GR expression from the 1A transcript

16 requires translation of the peptide encoded by uORF-2. The peptide was detectable in

17 both cells with naturally $1 \mathrm{~A}$ transcripts and cells transfected with $1 \mathrm{~A}$. The role of this

18 peptide in the regulation of the membrane GR is still unclear [50].

\section{Epigenetic programming of GR promoters}

21 Epigenetic methylation of the 5'-cytosine of a $\mathrm{CpG}$ dinucleotide is associated with gene

22 silencing either by inhibition of transcription factor binding (Fig. 2) or by chromatin

23 inactivation [51-53]. For instance, prenatal epigenetic methylation governs genomic 
1 imprinting and inactivation of one X-chromosome [54]. The epigenetic chromatin status

2 is sensitive to the host environment. Thus, epigenetic methylation represents a link

3 between the environment and gene activity. In particular, early life events can have a

4 long-lasting effect on epigenetic programming [52, 53]. In many instances, minor

5 changes in GR levels can have a significant impact, for example on feedback regulation

6 of the HPA axis, where hippocampal or pituitary GR levels determine the HPA axis set-

7 points and the response to stress.

8 Experimentally, maternal care such as licking-grooming (LG) and arched-back nursing

9 (ABN) has been shown to translate into epigenetic methylation of the GR promoter $1_{7}$

10 with profound and lasting effects on the stress response of the off-springs. [55]. The

11 NGFI-A binding site in the GR promoter $1_{7}$ (Fig. 3), homologous to the human 1F, was

12 highly methylated (>80\%) in the offspring of low caring mothers whereas it was rarely

13 methylated in the offspring of high caring rats [35]. As a result, binding of NGFI-A to the

14 GR $1_{7}$ promoter was inhibited in the hippocampus of offspring of low caring mothers and

15 GR $1_{7}$ expression was reduced [56]. Interestingly, these effects were reversed by cross-

16 fostering indicating a direct effect of maternal care on the epigenome of the offspring

17 [35]. Infusion of L-methionine reversed these effects on methylation and NGFI-A

18 binding to the exon $1_{7}$ promoter in the rat brain [57].

19 In Lewis and Fisher rats that naturally differ in their stress response and hippocampal GR

20 levels, the $1_{7}$ promoter was shown to be un- or poorly methylated throughout (mostly

21 below $10 \%$ and never exceeding 30\%), with no difference between the two strains.

22 Feeding these rats a methyl-supplemented diet had no significant effect on the GR

23 promoter $1_{7}$ methylation levels [58]. 
GR Transcription

1 Using the maternal separation model to change the stress response in rat pups (Table 2),

2 Daniels et al. observed elevated NGFI-A levels and significant behavioural changes. In

3 this model, the $1_{7}$ promoter, including both $\mathrm{CpG}$ sites within the NGFI-A binding site,

4 was uniformly un-methylated even after applying the maternal separation stressor [59].

5 Epigenetic programming of the GR is not limited to central tissues such as the

6 hippocampus. It has also been proposed that dietary restriction could lead to changes in

7 DNA methyl content, affecting epigenetic programming of the GR promoter both

8 centrally and peripherally [60]. Feeding a protein-restricted diet to pregnant dams lead to

9 a hypomethylation of the major GR promoter $1_{10}$ and to an increased expression of GR in

10 the liver of these rat pups [61].

11 These animal models showing changes in GR promoter methylation are not easily

12 transferred to humans. Nevertheless maternal adversities like depression or protein

13 restriction and their effects on the epigenome of offspring have been investigated (Table

14 2). Oberlander et al. showed that prenatal exposure to maternal depression leads to

15 increased methylation levels of the GR promoter $1 \mathrm{~F}$ at the NGFI-A binding site in cord

16 blood of newborns [62]. Like in most rat experiments, methylation levels were uniformly

17 low (5-10\%) with small but significant differences between children of depressed and

18 healthy mothers.

19 Several studies also investigated alterations in the human GR 1F promoter in specific

20 disease populations based on the rat $1_{7}$ data of Weaver et al. [35]. In neurological

21 disorders such as Parkinson's disease, Alzheimer's or dementia no hypermethylation of

22 the 1F promoter and the NGFI-A binding site could be found [63]. We showed that in

23 major depressive disorder there was no methylation of the NGFI-A binding site of the $1 \mathrm{~F}$ 
1 promoter in several regions of human post-mortem brains [26]. However, in suicide

2 victims with a history of child abuse, McGowan et al. found increased methylation

3 patterns compared to suicide victims without abuse [36]. In this study, methylation of

4 another putative NGFI-A binding site within promoter $1 \mathrm{~F}$ resulted in decreased

5 expression levels of $1 \mathrm{~F}$ transcripts and overall GR levels. The known NGFI-A binding

6 site was completely unmethylated in all of the suicide victims. Thus, it is possible that

7 other transcription factor binding sites are important for the transcriptional regulation of

8 the GR $1 \mathrm{~F}$ promoter and that these are more sensitive to epigenetic modifications.

9 Interestingly, in all four of the above studies [26, 36, 62, 63], levels of methylation were

10 always very low in comparison to those in the LG-ABN rats [35]. Investigating the

11 complete GR $\mathrm{CpG}$ island, we were able to show highly variable methylation patterns

12 among different GR promoters in PBMC's of healthy donors, suggesting that epigenetic

13 programming may not be restricted to the $1 \mathrm{~F}$ promoter, but operates throughout the $\mathrm{CpG}$

14 island [33]. It remains unclear, however, what triggers changes in methylation, and when

15 are the different tissues most susceptible to epigenetic programming. Despite some

16 contradictions it seems that levels of methylation are consistently low in the brain, and

17 somewhat higher and more variable at least in the blood mononuclear cells and liver.

19 The future - GR post-transcriptional regulation by miRNAs?

20 MicroRNAs (miRNAs) were discovered in 2001 [64, 65]. In mammalian, miRNAs were

21 predicted to regulate up to $30 \%$ of all genes [66]. So far they have been shown to be

22 involved in almost every cellular process investigated [67, 68]. It is now recognised that

23 miRNAs account for about $1 \%$ of the human genome and that they play a key role in 
GR Transcription

1 many regulatory pathways such as development timing, cell differentiation and apoptosis

2 [69]. MicroRNAs are single-stranded RNA molecules of about 21 nucleotides in length

3 that bind through imperfect base pairing to their target mRNAs, interfering with

4 translational output [70]. miRNAs can either be encoded within an intronic locus [71, 72]

5 or they cluster within intergenic regions [73]. miRNA gene transcription gives a primary

6 miRNA transcript (pri-miRNA) that after subsequent processing (reviewed in [74]) is

7 incorporated into the RNA Induced Silencing Complex (RISC). The seed region, a 6-8

8 nucleotide long sequence situated at the 5' end of the miRNA, nucleates the binding of

9 miRNAs to their mRNA targets, requiring several contiguous and perfect by matching

10 base pairs [75]. With a few exceptions, miRNA-binding sites in metazoan mRNA lie in

11 the 3'UTR of the target gene and are usually present in multiple copies [76-80]. The

12 exact mechanisms by which miRNAs repress translation remain unclear. However, it is

13 known that miRNAs not only induce mRNA deadenylation and degradation but they also

14 seem to interfere with protein synthesis [81].

15 There is now evidence that miRNAs are involved in the regulation of hippocampal GR

16 levels modulating the HPA axis responsiveness [82]. The 3' UTR of the GR was

17 predicted to contain numerous seed regions recognized by a variety of miRNAs two of

18 which were miR-18 and miR-124a [83]. Both reduced GR protein levels and the overall

19 GR activities measured by target gene expression levels. miR-18 inhibited GR mRNA

20 translation in cultured neuronal cells and was shown to be up-regulated in the

21 paraventricular nucleus of Fischer 344 rats, a strain hypersensitive to stress. Interestingly,

22 it has been known for some time that Fischer 344 rats have low GR levels in the

23 hippocampus compared to Lewis rats. Together, these results suggest a role of miR-18 in 
GR Transcription

1 GR down-regulation, increasing the vulnerability to repeated stress [84]. In contrast to

2 miR-18, which was expressed in numerous tissues, miR-124a expression was restricted to

3 certain brain regions and changed during the stress neonatal hyporesponsive period [85].

4 Little is known about miRNA targeting 5'UTRs, although target sites for endogenous

5 miRNAs can also be identified in these upstream gene regions. A recent study reported

6 mRNAs to be repressed as efficiently by miRNA binding in the $5^{\prime}$ as in the $3^{\prime}$ UTR

7 although previously 5' miRNAs were shown to be less effective than those binding in the

8 3'UTRs [86]. Most surprisingly, by binding to the 5'UTR, miRNA family member miR-

910 enhanced the translation of its target mRNA [87].

10 Nothing is known so far about miRNAs targeting the 5' UTR of GR mRNAs.

11 Considering the high variability of the GR 5'UTRs and tissue-dependent first exon usage

$12[19,30]$, it is attractive to hypothesise that miRNAs may add yet another layer of

13 transcriptional complexity to the GR. Using the online version of PITA (Probability of

14 Interaction by Target Accessibility) [88], we predicted a number of highly significant

15 miRNA binding sites within the GR first exon Figure (4). To determine if and how these

16 miRNAs are involved in GR posttranscriptional regulation remains a rewarding

17 challenge.

19 Summary

20 The studies presented in this review demonstrate the multiple layers of complexity

21 involved in the maintenance of the homeostasis of the ubiquitously expressed GR. Data

22 from our laboratory and others have shown that the multiple first exons represent a first

23 layer of complexity playing a particular role in tissue-specific transcriptional regulation. 
GR Transcription

1 The abundance of the alternative exons is modulated by epigenetic methylation of their

2 promoters. Finally, we suggest that the mature mRNA will be susceptible to miRNA

3 effects that are transcript specific. Whilst the amount of the GR is thought to be the main

4 determinant of the GC response, the third layer of complexity, beyond the scope of this

5 review is the interaction of the mature GR with its numerous co-regulators and co-

6 repressor proteins, as well as their interactions with the other steroid receptors upon

7 ligation.

9 Amongst the many open questions is the effect of the alternative 5' transcripts on

10 translation. It is likely that the 5'UTR sequence will affect the recruitment of the

11 translational machinery, translation rates, as well as mRNA stability. Together these will

12 further regulate the amount of GR generated, the ultimate determinant of GC sensitivity.

13 Determining how these different mechanisms converge to produce an adequate stress

14 response in the healthy and the sick is one of the next major challenges.

16 When we published the structure of the GR 5'UTR its complexity was unique. However,

17 over the last few years an unexpected variability in the 5' UTR of genes throughout the

18 complete genome has unfolded. In 2001 there were only 2 human genes known to have

$19>10$ first exons [89], in 2006 this had expanded to at least 43 [90]. Although there is no

20 more recent data, comprehensive analysis of the ENCODE project data suggests that

$21>20 \%$ of all human genes have multiple alternative promoters [91]. Data from the

22 Database of Transcription Start sites (DBTSS) even suggests that $>50 \%$ of all genes have

23 alternative first exons and associated promoters [92]. The discrepancy between these two 


\section{GR Transcription}

1 estimates is most probably due to the greater variety of tissue and cell types available in

2 the DBTSS, underscoring tissue specificity of these first exons. Thus, genes with

3 alternative first exons, translated or not, seem to be the rule rather than the exception as

4 initially thought for the GR.

5

6 
References:

[1] Kumar R, Thompson EB. Transactivation functions of the N-terminal domains of nuclear hormone receptors: protein folding and coactivator interactions. Mol Endocrinol 2003;17:1-10.

[2] DeRijk RH, Schaaf M, Stam FJ, de Jong IE, Swaab DF, Ravid R, et al. Very low levels of the glucocorticoid receptor beta isoform in the human hippocampus as shown by Taqman RT-PCR and immunocytochemistry. Brain Res Mol Brain Res 2003;116:17-26.

[3] Derijk RH, Schaaf MJ, Turner G, Datson NA, Vreugdenhil E, Cidlowski J, et al. A human glucocorticoid receptor gene variant that increases the stability of the glucocorticoid receptor beta-isoform mRNA is associated with rheumatoid arthritis. J Rheumatol 2001;28:2383-8.

[4] Schaaf MJ, Cidlowski JA. Molecular mechanisms of glucocorticoid action and resistance. J Steroid Biochem Mol Biol 2002;83:37-48.

[5] Lu NZ, Collins JB, Grissom SF, Cidlowski JA. Selective regulation of bone cell apoptosis by translational isoforms of the glucocorticoid receptor. Mol Cell Biol 2007;27:7143-60.

[6] Lu NZ, Cidlowski JA. Glucocorticoid receptor isoforms generate transcription specificity. Trends Cell Biol 2006;16:301-7.

[7] Lu NZ, Cidlowski JA. Translational regulatory mechanisms generate N-terminal glucocorticoid receptor isoforms with unique transcriptional target genes. Mol Cell 2005; 18:331-42.

[8] Bamberger CM, Schulte HM, Chrousos GP. Molecular determinants of glucocorticoid receptor function and tissue sensitivity to glucocorticoids. Endocr Rev 1996;17:245-61.

[9] Reichardt HM, Umland T, Bauer A, Kretz O, Schutz G. Mice with an increased glucocorticoid receptor gene dosage show enhanced resistance to stress and endotoxic shock. Mol Cell Biol 2000;20:9009-17.

[10] Ridder S, Chourbaji S, Hellweg R, Urani A, Zacher C, Schmid W, et al. Mice with genetically altered glucocorticoid receptor expression show altered sensitivity for stress-induced depressive reactions. J Neurosci 2005;25:6243-50.

[11] van der Laan S, Lachize SB, Vreugdenhil E, de Kloet ER, Meijer OC. Nuclear receptor coregulators differentially modulate induction and glucocorticoid receptor-mediated repression of the corticotropin-releasing hormone gene. Endocrinology 2008;149:725-32.

[12] Hollenberg SM, Weinberger C, Ong ES, Cerelli G, Oro A, Lebo R, et al. Primary structure and expression of a functional human glucocorticoid receptor cDNA. Nature 1985;318:635-41.

[13] Barrett TJ, Vig E, Vedeckis WV. Coordinate regulation of glucocorticoid receptor and c-jun gene expression is cell type-specific and exhibits differential hormonal sensitivity for down- and up-regulation. Biochemistry 1996;35:9746-53.

[14] Wei P, Vedeckis WV. Regulation of the glucocorticoid receptor gene by the AP-1 transcription factor. Endocrine 1997;7:303-10.

[15] Breslin MB, Vedeckis WV. The human glucocorticoid receptor promoter upstream sequences contain binding sites for the ubiquitous transcription factor, Yin Yang 1. J Steroid Biochem Mol Biol 1998;67:369-81. 
[16] Breslin MB, Geng CD, Vedeckis WV. Multiple promoters exist in the human GR gene, one of which is activated by glucocorticoids. Mol Endocrinol 2001;15:1381-95.

[17] Nunez BS, Vedeckis WV. Characterization of promoter $1 \mathrm{~B}$ in the human glucocorticoid receptor gene. Mol Cell Endocrinol 2002;189:191-9.

[18] Geng CD, Vedeckis WV. Steroid-responsive sequences in the human glucocorticoid receptor gene 1A promoter. Mol Endocrinol 2004;18:912-24.

[19] Turner JD, Muller CP. Structure of the glucocorticoid receptor (NR3C1) gene 5' untranslated region: identification, and tissue distribution of multiple new human exon 1. J Mol Endocrinol 2005;35:283-92.

[20] Presul E, Schmidt S, Kofler R, Helmberg A. Identification, tissue expression, and glucocorticoid responsiveness of alternative first exons of the human glucocorticoid receptor. J Mol Endocrinol 2007;38:79-90.

[21] Pickering BM, Willis AE. The implications of structured 5' untranslated regions on translation and disease. Semin Cell Dev Biol 2005;16:39-47.

[22] Kornblihtt AR. Promoter usage and alternative splicing. Current opinion in Cell Biology 2005.

[23] Didier Auboeuf DHD, Yun Kyoung Kang. Differential recruitment of nuclear receptor coactivators may determine alternative RNA splice site choice in target genes. PNAS 2003;101.

[24] Pedersen KB, Vedeckis WV. Quantification and glucocorticoid regulation of glucocorticoid receptor transcripts in two human leukemic cell lines. Biochemistry 2003;42:10978-90.

[25] Russcher H, Dalm VA, de Jong FH, Brinkmann AO, Hofland LJ, Lamberts SW, et al. Associations between promoter usage and alternative splicing of the glucocorticoid receptor gene. J Mol Endocrinol 2007;38:91-8.

[26] Alt SR, Turner JD, Klok MD, Meijer OC, Lakke EA, Derijk RH, et al. Differential expression of glucocorticoid receptor transcripts in major depressive disorder is not epigenetically programmed. Psychoneuroendocrinology 2010;35:544-56.

[27] Zong J, Ashraf J, Thompson EB. The promoter and first, untranslated exon of the human glucocorticoid receptor gene are GC rich but lack consensus glucocorticoid receptor element sites. Mol Cell Biol 1990;10:5580-5.

[28] Nobukuni Y, Smith CL, Hager GL, Detera-Wadleigh SD. Characterization of the human glucocorticoid receptor promoter. Biochemistry 1995;34:8207-14.

[29] Shrivastava A, Calame K. An analysis of genes regulated by the multi-functional transcriptional regulator Yin Yang-1. Nucleic Acids Res 1994;22:5151-5.

[30] Turner JD, Schote AB, Macedo JA, Pelascini LP, Muller CP. Tissue specific glucocorticoid receptor expression, a role for alternative first exon usage? Biochem Pharmacol 2006;72:1529-37.

[31] Breslin MB, vedeckis WV. The Glucocorticoid Receptor and c-jun Promoters Contain AP-1 Sites That Bind Different AP-1 Transcription factors. Endocrine 1996;5:15-22.

[32] Warriar N, Page N, Govindan MV. Expression of human glucocorticoid receptor gene and interaction of nuclear proteins with the transcriptional control element. $\mathrm{J}$ Biol Chem 1996;271:18662-71. 
[33] LeClerc S, Palaniswami R, Xie BX, Govindan MV. Molecular cloning and characterization of a factor that binds the human glucocorticoid receptor gene and represses its expression. J Biol Chem 1991;266:17333-40.

[34] Leclerc S, Xie BX, Roy R, Govindan MV. Purification of a human glucocorticoid receptor gene promoter-binding protein. Production of polyclonal antibodies against the purified factor. J Biol Chem 1991;266:8711-9.

[35] Weaver IC, Cervoni N, Champagne FA, D'Alessio AC, Sharma S, Seckl JR, et al. Epigenetic programming by maternal behavior. Nat Neurosci 2004;7:847-54.

[36] McGowan PO, Sasaki A, D'Alessio AC, Dymov S, Labonte B, Szyf M, et al. Epigenetic regulation of the glucocorticoid receptor in human brain associates with childhood abuse. Nat Neurosci 2009;12:342-8.

[37] Geng CD, Schwartz JR, Vedeckis WV. A conserved molecular mechanism is responsible for the auto-up-regulation of glucocorticoid receptor gene promoters. Mol Endocrinol 2008;22:2624-42.

[38] Turner JD, Pelascini LP, Macedo JA, Muller CP. Highly individual methylation patterns of alternative glucocorticoid receptor promoters suggest individualized epigenetic regulatory mechanisms. Nucleic Acids Res 2008;36:7207-18.

[39] Strahle U, Schmidt A, Kelsey G, Stewart AF, Cole TJ, Schmid W, et al. At least three promoters direct expression of the mouse glucocorticoid receptor gene. Proc Natl Acad Sci U S A 1992;89:6731-5.

[40] McCormick JA, Lyons V, Jacobson MD, Noble J, Diorio J, Nyirenda M, et al. 5'heterogeneity of glucocorticoid receptor messenger RNA is tissue specific: differential regulation of variant transcripts by early-life events. Mol Endocrinol 2000;14:506-17.

[41] Chen F, Watson CS, Gametchu B. Association of the glucocorticoid receptor alternatively-spliced transcript $1 \mathrm{~A}$ with the presence of the high molecular weight membrane glucocorticoid receptor in mouse lymphoma cells. J Cell Biochem 1999;74:430-46.

[42] Tissing WJ, Meijerink JP, Brinkhof B, Broekhuis MJ, Menezes RX, den Boer ML, et al. Glucocorticoid-induced glucocorticoid receptor expression and promoter-usage is not linked to glucocorticoid resistance in childhood ALL. Blood 2006.

[43] Chen F, Watson CS, Gametchu B. Multiple glucocorticoid receptor transcripts in membrane glucocorticoid receptor-enriched S-49 mouse lymphoma cells. J Cell Biochem 1999;74:418-29.

[44] Geng CD, Pedersen KB, Nunez BS, Vedeckis WV. Human glucocorticoid receptor alpha transcript splice variants with exon 2 deletions: evidence for tissueand cell type-specific functions. Biochemistry 2005;44:7395-405.

[45] Nunez BS, Geng CD, Pedersen KB, Millro-Macklin CD, Vedeckis WV. Interaction between the Interferon Signaling Pathway and the Human Glucocorticoid Receptor Gene 1A Promoter. Endocrinology 2005;146:1449-57.

[46] Gametchu B, Watson CS. Correlation of membrane glucocorticoid receptor levels with glucocorticoid-induced apoptotic competence using mutant leukemic and lymphoma cells lines. J Cell Biochem 2002;87:133-46. 
[47] Gametchu B, Watson CS, Shih CC, Dashew B. Studies on the arrangement of glucocorticoid receptors in the plasma membrane of S-49 lymphoma cells. Steroids 1991;56:411-9.

[48] Bartholome B, Spies CM, Gaber T, Schuchmann S, Berki T, Kunkel D, et al. Membrane glucocorticoid receptors (mGCR) are expressed in normal human peripheral blood mononuclear cells and up-regulated after in vitro stimulation and in patients with rheumatoid arthritis. Faseb J 2004;18:70-80.

[49] Spies CM, Schaumann DH, Berki T, Mayer K, Jakstadt M, Huscher D, et al. Membrane glucocorticoid receptors are down regulated by glucocorticoids in patients with systemic lupus erythematosus and use a caveolin-1-independent expression pathway. Ann Rheum Dis 2006;65:1139-46.

[50] Diba F, Watson CS, Gametchu B. 5'UTR sequences of the glucocorticoid receptor 1A transcript encode a peptide associated with translational regulation of the glucocorticoid receptor. J Cell Biochem 2001;81:149-61.

[51] Bird A. Perceptions of epigenetics. Nature 2007;447:396-8.

[52] Meaney MJ, Szyf M, Seckl JR. Epigenetic mechanisms of perinatal programming of hypothalamic-pituitary-adrenal function and health. Trends Mol Med 2007; 13:269-77.

[53] Szyf M. The early life environment and the epigenome. Biochim Biophys Acta 2009; 1790:878-85.

[54] Bird A. DNA methylation patterns and epigenetic memory. Genes Dev 2002;16:6-21.

[55] Weaver IC. Epigenetic programming by maternal behavior and pharmacological intervention. Nature versus nurture: let's call the whole thing off. Epigenetics 2007;2:22-8.

[56] Weaver IC, D'Alessio AC, Brown SE, Hellstrom IC, Dymov S, Sharma S, et al. The transcription factor nerve growth factor-inducible protein a mediates epigenetic programming: altering epigenetic marks by immediate-early genes. J Neurosci 2007;27:1756-68.

[57] Weaver IC, Champagne FA, Brown SE, Dymov S, Sharma S, Meaney MJ, et al. Reversal of maternal programming of stress responses in adult offspring through methyl supplementation: altering epigenetic marking later in life. J Neurosci 2005;25:11045-54.

[58] Herbeck YE, Gulevich RG, Amelkina OA, Plyusnina IZ, Oskina IN. Conserved methylation of the glucocorticoid receptor gene exon 1(7) promoter in rats subjected to a maternal methyl-supplemented diet. Int J Dev Neurosci 2010;28:912.

[59] Daniels WM, Fairbairn LR, van Tilburg G, McEvoy CR, Zigmond MJ, Russell VA, et al. Maternal separation alters nerve growth factor and corticosterone levels but not the DNA methylation status of the exon 1(7) glucocorticoid receptor promoter region. Metab Brain Dis 2009;24:615-27.

[60] McGowan PO, Meaney MJ, Szyf M. Diet and the epigenetic (re)programming of phenotypic differences in behavior. Brain Res 2008;1237:12-24.

[61] Lillycrop KA, Slater-Jefferies JL, Hanson MA, Godfrey KM, Jackson AA, Burdge GC. Induction of altered epigenetic regulation of the hepatic glucocorticoid receptor in the offspring of rats fed a protein-restricted diet during 
pregnancy suggests that reduced DNA methyltransferase- 1 expression is involved in impaired DNA methylation and changes in histone modifications. Br J Nutr 2007;97:1064-73.

[62] Oberlander TF, Weinberg J, Papsdorf M, Grunau R, Misri S, Devlin AM. Prenatal exposure to maternal depression, neonatal methylation of human glucocorticoid receptor gene (NR3C1) and infant cortisol stress responses. Epigenetics 2008;3:97-106.

[63] Moser D, Molitor A, Kumsta R, Tatschner T, Riederer P, Meyer J. The glucocorticoid receptor gene exon 1-F promoter is not methylated at the NGFI-A binding site in human hippocampus. World J Biol Psychiatry 2007;8:262-8.

[64] Lim LP, Lau NC, Weinstein EG, Abdelhakim A, Yekta S, Rhoades MW, et al. The microRNAs of Caenorhabditis elegans. Genes Dev 2003;17:991-1008.

[65] Lee RC, Ambros V. An extensive class of small RNAs in Caenorhabditis elegans. Science 2001;294:862-4.

[66] Filipowicz W, Bhattacharyya SN, Sonenberg N. Mechanisms of posttranscriptional regulation by microRNAs: are the answers in sight? Nat Rev Genet 2008;9:102-14.

[67] Bushati N, Cohen SM. microRNA functions. Annu Rev Cell Dev Biol 2007;23:175-205.

[68] Kloosterman WP, Plasterk RH. The diverse functions of microRNAs in animal development and disease. Dev Cell 2006;11:441-50.

[69] Bartel DP. MicroRNAs: genomics, biogenesis, mechanism, and function. Cell 2004;116:281-97.

[70] Bagga S, Bracht J, Hunter S, Massirer K, Holtz J, Eachus R, et al. Regulation by let-7 and lin-4 miRNAs results in target mRNA degradation. Cell 2005;122:55363.

[71] Cai X, Hagedorn $\mathrm{CH}$, Cullen BR. Human microRNAs are processed from capped, polyadenylated transcripts that can also function as mRNAs. RNA 2004;10:195766.

[72] Lee Y, Kim M, Han J, Yeom KH, Lee S, Baek SH, et al. MicroRNA genes are transcribed by RNA polymerase II. EMBO J 2004;23:4051-60.

[73] Lee Y, Jeon K, Lee JT, Kim S, Kim VN. MicroRNA maturation: stepwise processing and subcellular localization. EMBO J 2002;21:4663-70.

[74] Kim VN. MicroRNA biogenesis: coordinated cropping and dicing. Nat Rev Mol Cell Biol 2005;6:376-85.

[75] Knight SW, Bass BL. A role for the RNase III enzyme DCR-1 in RNA interference and germ line development in Caenorhabditis elegans. Science 2001;293:2269-71.

[76] Brennecke J, Stark A, Russell RB, Cohen SM. Principles of microRNA-target recognition. PLoS Biol 2005;3:e85.

[77] Doench JG, Sharp PA. Specificity of microRNA target selection in translational repression. Genes Dev 2004;18:504-11.

[78] Grimson A, Farh KK, Johnston WK, Garrett-Engele P, Lim LP, Bartel DP. MicroRNA targeting specificity in mammals: determinants beyond seed pairing. Mol Cell 2007;27:91-105. 
[79] Lewis BP, Burge CB, Bartel DP. Conserved seed pairing, often flanked by adenosines, indicates that thousands of human genes are microRNA targets. Cell 2005; 120:15-20.

[80] Nielsen CB, Shomron N, Sandberg R, Hornstein E, Kitzman J, Burge CB. Determinants of targeting by endogenous and exogenous microRNAs and siRNAs. RNA 2007;13:1894-910.

[81] Behm-Ansmant I, Rehwinkel J, Doerks T, Stark A, Bork P, Izaurralde E. mRNA degradation by miRNAs and GW182 requires both CCR4:NOT deadenylase and DCP1:DCP2 decapping complexes. Genes Dev 2006;20:1885-98.

[82] de Kloet ER, Fitzsimons CP, Datson NA, Meijer OC, Vreugdenhil E. Glucocorticoid signaling and stress-related limbic susceptibility pathway: about receptors, transcription machinery and microRNA. Brain Res 2009;1293:129-41.

[83] Uchida S, Nishida A, Hara K, Kamemoto T, Suetsugi M, Fujimoto M, et al. Characterization of the vulnerability to repeated stress in Fischer 344 rats: possible involvement of microRNA-mediated down-regulation of the glucocorticoid receptor. Eur J Neurosci 2008;27:2250-61.

[84] Lytle JR, Yario TA, Steitz JA. Target mRNAs are repressed as efficiently by microRNA-binding sites in the 5' UTR as in the 3' UTR. Proc Natl Acad Sci U S A 2007;104:9667-72.

[85] Vreugdenhil E, Verissimo CS, Mariman R, Kamphorst JT, Barbosa JS, Zweers T, et al. MicroRNA 18 and $124 \mathrm{a}$ down-regulate the glucocorticoid receptor: implications for glucocorticoid responsiveness in the brain. Endocrinology 2009; 150:2220-8.

[86] Farh KK, Grimson A, Jan C, Lewis BP, Johnston WK, Lim LP, et al. The widespread impact of mammalian MicroRNAs on mRNA repression and evolution. Science 2005;310:1817-21.

[87] Orom UA, Nielsen FC, Lund AH. MicroRNA-10a binds the 5'UTR of ribosomal protein mRNAs and enhances their translation. Mol Cell 2008;30:460-71.

[88] Kertesz M, Iovino N, Unnerstall U, Gaul U, Segal E. The role of site accessibility in microRNA target recognition. Nat Genet 2007;39:1278-84.

[89] Zhang T, Haws P, Wu Q. Multiple variable first exons: a mechanism for cell- and tissue-specific gene regulation. Genome Res 2004;14:79-89.

[90] Kimura K, Wakamatsu A, Suzuki Y, Ota T, Nishikawa T, Yamashita R, et al. Diversification of transcriptional modulation: large-scale identification and characterization of putative alternative promoters of human genes. Genome Res 2006;16:55-65.

[91] Cooper SJ, Trinklein ND, Anton ED, Nguyen L, Myers RM. Comprehensive analysis of transcriptional promoter structure and function in $1 \%$ of the human genome. Genome Res 2006;16:1-10.

[92] Tsuritani K, Irie T, Yamashita R, Sakakibara Y, Wakaguri H, Kanai A, et al. Distinct class of putative "non-conserved" promoters in humans: comparative studies of alternative promoters of human and mouse genes. Genome Res 2007; 17:1005-14. 
GR Transcription

Figure 1: Structure of the GR gene (NR3C1; OMIM + 138040; NR3C1; 5q31-q32), the potential mRNA transcripts and the binding sites within the $\mathrm{CpG}$ island.

Panel A The genomic structure of the GR. I 5 ' untranslated distal exons; $\square$ 5'untranslated CpG island exons; $\square$ Common exons; $⿴$ 3' alternatively spliced exons. Panel B shows the potential mRNA transcripts encoding the three GR isoforms: GR $\alpha$, GR $\beta$ and GR-P. Panel $\mathrm{B}$ shows the location of the known transcription factor binding sites. $\mathbb{N}$ IRF 1 and IRF2 (position 1); $\mathbf{D}$ c-Myb, c-Ets 1/2 and PU1 (position 4); $\boldsymbol{\nabla}$ Ying Yand 1 (positions 5,6,7 and 25); $\square$ Glucocorticoid response elements (GRE, positions 2, 3, 8, 21, and 22); $\square$ Sp1 binding sites (positions 9, 10, 12, 13, 16, 19, 20, 21, and 24); $\square$ NGFIA binding site (position 17); 团 Glucocorticoid response factor-1 (GRF1, position 18); 目 Ap-1 (position 15); and $\mathrm{D}$ Ap-2 (position 23).

Figure 2: DNA methylation inhibits transcriptional regulation of genes.

A complex of transcription factors (TF), the DNA polymerase (Pol) and co-activators (open circles) normally binds to the GR promoter and thus regulates gene expression.

Epigenetic modifications can lead to methylation of the transcription factor binding site in the GR promoter (full ovals). Therefore binding to the promoter is inhibited and expression of the GR is reduced. Figure from [26] with permission.

Figure 3: Alignment of the rat GR promoter $1_{7}$ and the human GR promoter $1 \mathrm{~F}$.

Solid-lined boxes represent known canonical NGFI-A binding sites either in the rat [35, 58, 59] or the human [38, 26, 62, 63] promoter. The broken-lined box in the human $1 \mathrm{~F}$ promoter represents a hypothetical non-canonical NGFI-A binding site [36].

Figure 4: The GR first exon $1 \mathrm{C}$ is rich in potential microRNA binding sites.

MicroRNA binding was predicted based on the probability of interaction by target accessibility (PITA) [88]. Individual binding scores are from the colour scale. Values lower then -11 are normally considered highly relevant. 


\section{Table 1. Transcription factor binding sites in the hGR proximal promoter region}

\begin{tabular}{|c|c|c|c|c|c|c|c|c|}
\hline \multirow{2}{*}{ Promoter } & \multirow[t]{2}{*}{$\mathrm{TF}^{\mathrm{a}}$} & \multirow{2}{*}{$\mathbf{N}^{\circ}$} & \multirow[t]{3}{*}{ Sequences } & \multirow{2}{*}{ Cell lines / Tissues } & \multirow[t]{2}{*}{ Technique $^{\mathrm{b}}$} & \multicolumn{2}{|c|}{ Location $^{\mathrm{c}}$} & \multirow[t]{2}{*}{ reference } \\
\hline & & & & & & $\overline{\text { start }}$ & end & \\
\hline \multicolumn{8}{|c|}{ Distal Promoter } & \\
\hline & IRF-1 & & GTAGAGGCGAATCACTTTCACTTCTGCTGGG & CEM-C7 & FP, EMSA, RG & -34574 & -34544 & {$[16,45]$} \\
\hline & IRF-2 & & GTAGAGGCGAATCACTTTCACTTCTGCTGGG & CEM-C7, Jurkat & FP, EMSA, RG & -34574 & -34544 & {$[16,45]$} \\
\hline & GR- $\alpha$ & & TCTGATACCAAATCACTGGACCTTA & CEM-C7 & FP, EMSA & -34490 & -34466 & {$[18]$} \\
\hline & GR- $\alpha$ & & GACCGTAAAATGCGCATG & CEM-C7, IM-9 & FP, EMSA, ChIP & -34436 & -34419 & {$[18,37,44]$} \\
\hline & GR- $\beta$ & & GAGAAGGAGAAAACTTAGATCTTCTGATACCAA & CEM-C7 & FP, EMSA & -34512 & -34480 & [16] \\
\hline & c-Myb & & ATGTGTCCAACGGAAGCACT & CEM-C7 & FP, EMSA, ChIP & -34421 & -34402 & {$[18,44]$} \\
\hline & c-Ets $1 / 2$ & & ATGTGTCCAACGGAAGCACT & CEM-C7 & FP, EMSA & -34421 & -34402 & [18] \\
\hline & PU.1 & & ATGTGTCCAACGGAAGCACT & IM-9 & EMSA, ChIP & -34421 & -34402 & {$[37,44]$} \\
\hline \multicolumn{9}{|c|}{ Proximal promoter } \\
\hline \multirow[t]{4}{*}{ 1D } & dYY1 & 1 & CCAAGATGG & $\mathrm{NIH}$ 3Т3, Hela & $F P, D, E$ & -4807 & -4799 & [15] \\
\hline & mYY1 & 2 & CCAAGATGG & $\mathrm{NIH} 3 \mathrm{~T} 3$, Hela & $F P, D, E$ & -4635 & -4627 & [15] \\
\hline & pYY1 & 3 & CCAAGATGG & NIH 3T3, Hela & $F P, D, E$ & -4591 & -4583 & [15] \\
\hline & GRE & 4 & GGCTTCCGGGACGCGCTTCCCCAATCGTCTTCAAG & Jurkat, IM-9, CEM-C7 & ChIP, E & -4574 & -4540 & [37] \\
\hline \multirow[t]{2}{*}{$1 \mathrm{~J}$} & Sp1 & 5 & GCTGGGGCGGGGGCTT & NIH 3T3, Hela & $F P, E$ & -4250 & -4235 & [15] \\
\hline & Sp1 & 6 & TTCGGGGGTGGGG & Jurkat, HepG2, Hela & $R G, F P, E$ & -4011 & -3999 & [17] \\
\hline $1 \mathrm{E}$ & GRE & 7 & GTGGAAGAAGAGGTCAGGAGTTTC & Jurkat, IM-9, CEM-C7 & ChIP, E & -3962 & -3939 & [37] \\
\hline \multirow[t]{2}{*}{ 1B } & Sp1 & 8 & CACATTGGGCGGGAGGGG & Jurkat, HepG2, Hela & $R G, F P, E$ & -3774 & -3757 & [17] \\
\hline & Sp1 & 9 & TTGAACTTGGCAGGCGGCGCC & Jurkat, HepG2, Hela & $R G, F P, E$ & -3750 & -3730 & [17] \\
\hline \multirow[t]{6}{*}{$1 \mathrm{~F}$} & GRE & 10 & GCACCGTTTCCGTGCAACCCCGTAGCCCCTTTCGAAGTGACACACT & Jurkat, IM-9, CEM-C7 & ChIP, E & -3438 & -3393 & [37] \\
\hline & AP-1 & 11 & TGACACA (consensus TGAC/GTCA) & AtT-20,NIH3T3 & EMSA & -3401 & -3395 & [31][14] \\
\hline & Sp1 & 12 & TGGGCGGGGGCGGGAA & Hela, NIH3T3, CV1, HepG2 & RG, FP, EMSA & -3228 & -3213 & [28] \\
\hline & NGFIA & 13 & GGGCGGGGGCGG & Rat Hippocampi / HEK293 & ChIP & -3227 & -3216 & {$[35,36]$} \\
\hline & GRF-1 & 14 & GAAGGAGGTAGCGAGAAAAGAAACTGGAGAAACTCGGTGG & MCF7, CV-1 & EMSA & -3215 & -3176 & {$[33,34]$} \\
\hline & Sp1 & 15 & TCTTAACGCCGCCCCAGAGA & Hela, NIH3T3, CV1, HepG2 & $R G, F P, E M S A$ & -3172 & -3153 & {$[28]$} \\
\hline \multirow[t]{6}{*}{$1 C$} & Sp1 & 16 & GGAGTTGGGGGCGGGGGGCG & Hela, NIH3T3, CV1, HepG2 & RG, FP, EMSA & -3107 & -3088 & [28] \\
\hline & Sp1 & 17 & GCGCACCGGGCGGGGCGGCC & Hela, NIH3T3, CV1, HepG2 & $R G, F P, E M S A$ & -3080 & -3061 & [28] \\
\hline & GRE & 18 & CTGCAGTTGCCAAGCGTCACCAACAGGTTGCATCGTTCCCC & Jurkat, IM-9, CEM-C7 & ChIP, E & -2971 & -2931 & [37] \\
\hline & AP-2 & 19 & CCGCGCGGCCCCTCGGGCGGGGA & Hela, NIH3T3, CV1, HepG2 & RG, FP, EMSA & -2923 & -2901 & [28] \\
\hline & Sp1 & 20 & CGCCGTGGCGCCGCCTCCA & Hela, NIH3T3, CV1, HepG2 & RG, FP, EMSA & -2856 & -2838 & [28] \\
\hline & iYY1 & 21 & CTCCTCCATTTTG & $\mathrm{NIH} 3 \mathrm{~T} 3, \mathrm{Hela}$ & $F P, D, E$ & -2755 & -2743 & [28] \\
\hline
\end{tabular}

${ }^{a}$ TF: Transcription Factor

${ }^{b}$ RG: reporter gene. FP: DNAse protection / DNA footprinting. ChIP: chromation precipitation. D: deletion analysis. EMSA: electrophoretic mobility shift assay

${ }^{c}$ Locationswith repect to the ATG start codon in exon 2. 


\section{Table 2: Methylation analyses of GR promoter regions}

\begin{tabular}{|c|c|c|c|c|c|c|c|}
\hline GR promoter & Species & Model & Method & Tissue & $\begin{array}{c}\text { Overall } \\
\text { methylation levels } \\
\end{array}$ & CpG specific comments † & Reference \\
\hline 1.7 & r. nor. & LG-ABN & colony sequencing & hippocampus & $<100 \%$ & $\begin{array}{l}80-100 \% \text { at CpG } 16-17 \text { in Low LG-ABN } \\
0-10 \% \text { at CpG } 16-17 \text { in High LG-ABN }\end{array}$ & [35] \\
\hline 1.7 & r. nor. & met sup & colony sequencing & hippocampus & $<15 \%$ & at $\mathrm{CpG} 16-17$ & [58] \\
\hline 1.7 & r. nor. & maternal sep & direct sequencing & hippocampus & not detected & at $\mathrm{CpG} 16-17$ & [59] \\
\hline 1.10 & r. nor. & PR diet & MS-PCR & liver & unknown & relative to control & [61] \\
\hline $1 \mathrm{D}$ & h. sap. & HV & colony sequencing & PBMCs & $<50 \%$ & stochastic and unique & [38] \\
\hline $1 \mathrm{E}$ & h. sap. & HV & colony sequencing & PBMCs & $>25 \%$ & stochastic and unique & [38] \\
\hline $1 \mathrm{~F}$ & h. sap. & HV & colony sequencing & PBMCs & $<10 \%$ & at CpG 37-38 & [38] \\
\hline $1 \mathrm{H}$ & h. sap. & HV & colony sequencing & PBMCs & $<75 \%$ & stochastic and unique & [38] \\
\hline $1 F$ & h. sap. & Dep & pyrosequencing & cord blood & $<7 \%$ & $<5 \%$ at $\mathrm{CpG} 37-38$ & [62] \\
\hline $1 \mathrm{~F}$ & h. sap. & Dep, Al, Park, Dem & MS-PCR & hippocampus & $<10 \%$ & $\begin{array}{l}\text { only } 1 \text { subject had visible methylation } \\
\text { all other donors unmethylated }\end{array}$ & [63] \\
\hline $1 \mathrm{~F}$ & h. sap. & Suicide / abuse & colony sequencing & hippocampus & $<40 \%$ & $0 \%$ at CpG $37-38$ & [36] \\
\hline $1 \mathrm{~B}$ & h. sap. & MDD & pyrosequencing & hippocampus & $0-12 \%$ & & {$[26]$} \\
\hline $1 \mathrm{E}$ & h. sap. & MDD & pyrosequencing & hippocampus & $4-9 \%$ & & [26] \\
\hline $1 F$ & h. sap. & MDD & pyrosequencing & hippocampus & $0-4 \%$ & $0-2 \%$ at $\mathrm{CpG} 37-38$ & {$[26]$} \\
\hline $1 \mathrm{~J}$ & h. sap. & MDD & pyrosequencing & hippocampus & $0-7 \%$ & & [26] \\
\hline
\end{tabular}

$\dagger$ all CpG numbers as in Figure 3

Abbreviations: r. nor, rattus norwegicus; h. sap, homo sapiens; LG-ABN, licking-grooming and arched-back nursing; met sup, methy-supplemented diet; maternal sep, maternal seperation; PR, protein-restricted; HV, healthy volunteer; Dep, depression; Al, Alzheimer's disease; Park, Parkinson's disease; Dem, dementia; MDD, major depressive disorder; MS-PCR, methylation-specific PCR 


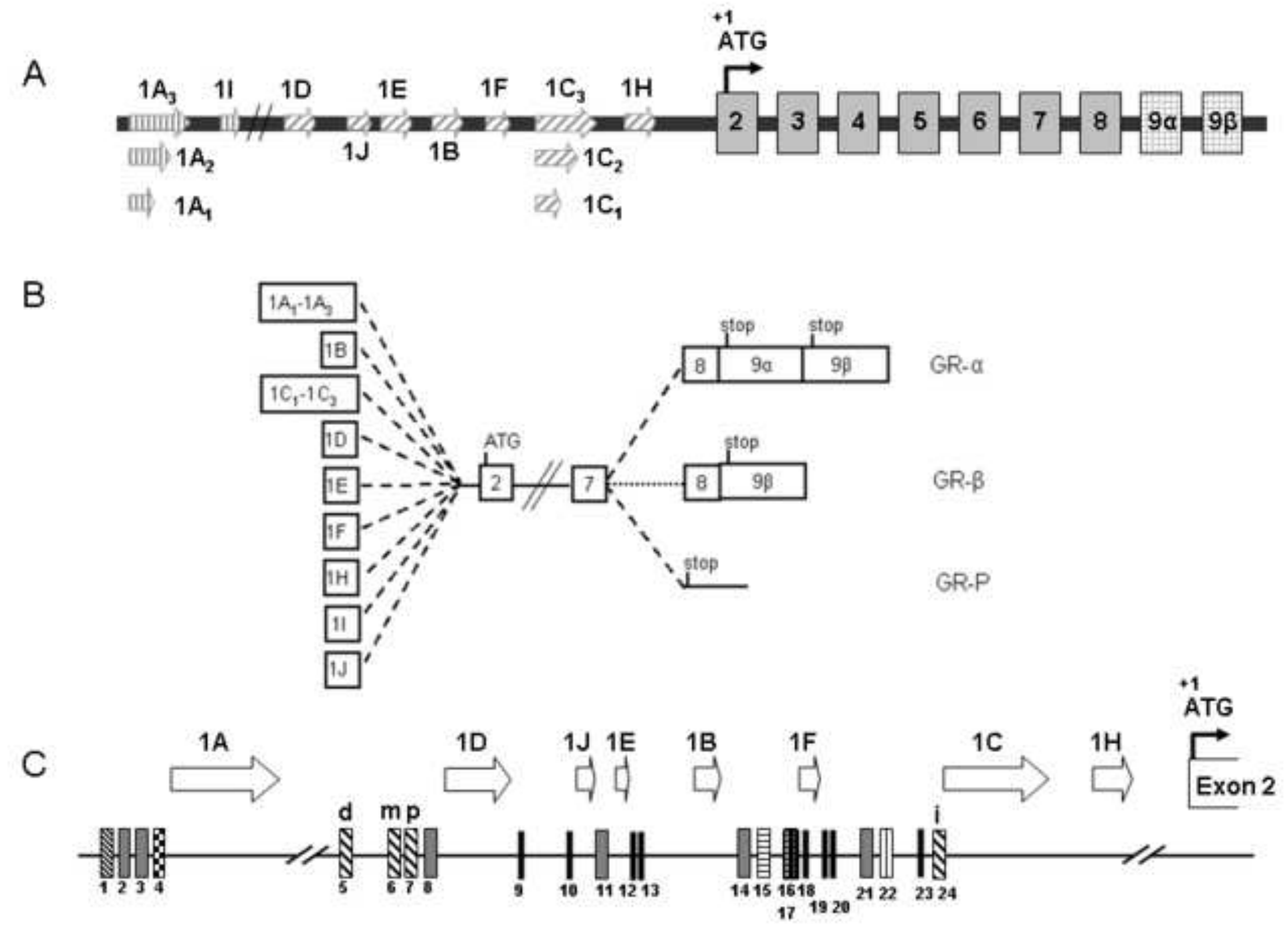


GR promoter

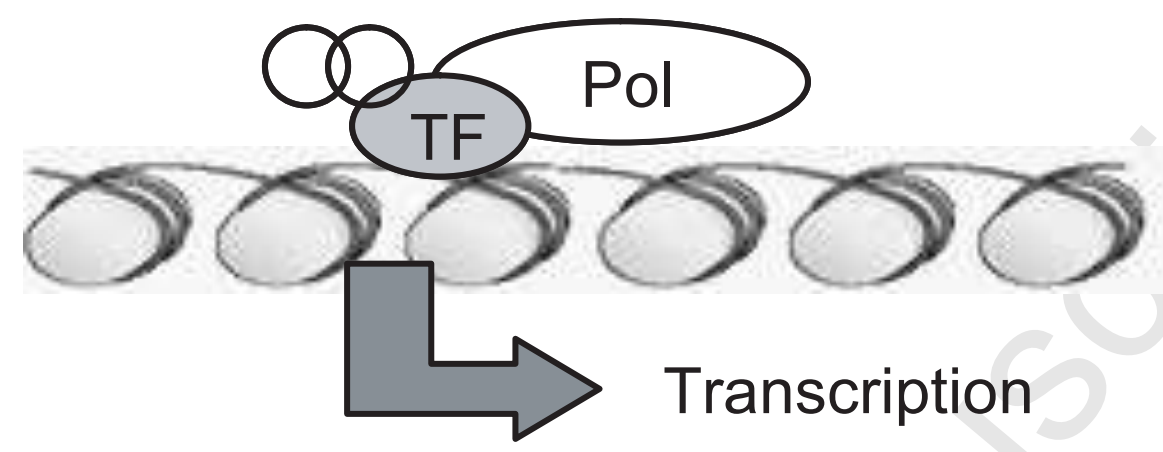

GR promoter

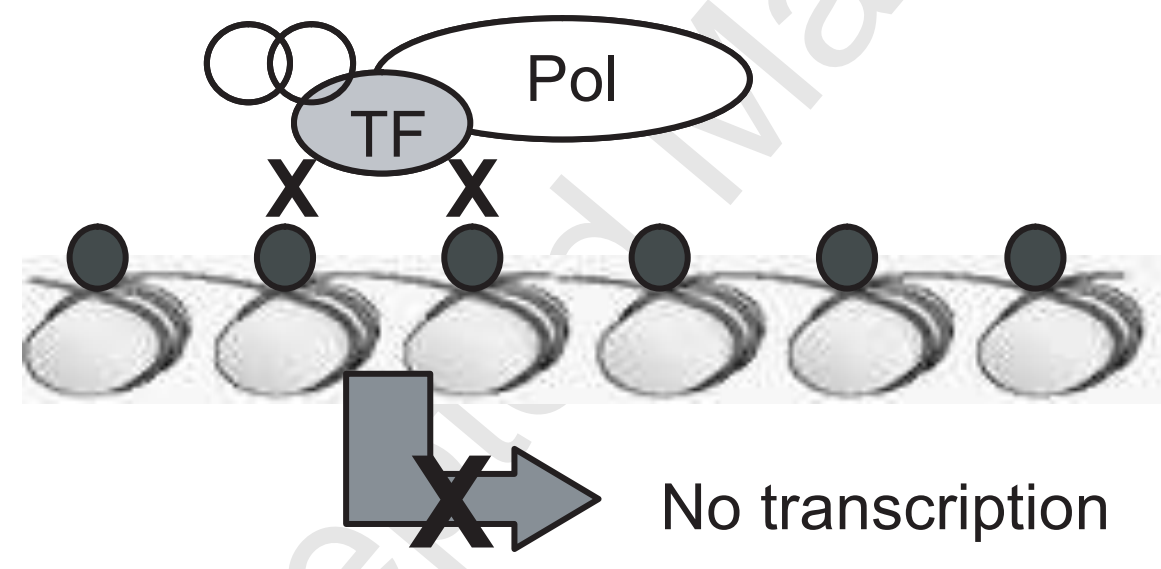

Figure 2 
2750

Rat (1698) GGCCAGGGCTCTGCGGCACCGTTTCCGTGCCATCCT GTAGCCCCTCTG CTAGTGTGACACACTTC $\mathrm{GC}^{2} \mathrm{GCAACTC}^{3} \mathrm{GCA}^{-}$

Human (2494) GGCCGAGACGCTGCGGCACCGTTTCCGTGCAACCCC ${ }^{12}$ GTAGCCCCTTTC $^{13}$ GAAGTG--ACACACTTC AC ${ }^{14}$ GCAACTC $^{15} \mathrm{G}_{\text {GCCC }}$ G $^{16}$

2830

2899

Rat (1795) GTT GGC ${ }^{4}$ GG- $-\mathrm{GC}^{5} \mathrm{GC}^{6} \mathrm{GGACCAC}$ CCCT $\mathrm{GC}^{7} \mathrm{GGCTCTGCC}^{8} \mathrm{G}-$

TG G

Human (2592) $\mathrm{GGC}^{17} \mathrm{GGC}^{18} \mathrm{GGC}^{19} \mathrm{GGC}^{20} \mathrm{GC}^{21} \mathrm{GGGCCAC} \quad \mathrm{TCAC}^{22} \mathrm{GC}$ AGCTCAGCC ${ }^{23} \mathrm{GC}^{24} \mathrm{GGGAGGC}^{25} \mathrm{GCCCC}^{26} \mathrm{GGCTCTTGTGGCCC}^{27} \mathrm{GCCC}^{28} \mathrm{G}$

Rat 2900 3002 Human (1857) CTGTCACCC TC GGGGGCTCTGGC TGC ----- $C^{10} \mathrm{G}$ ACCCAC ${ }^{11} \mathrm{GGG}----\mathrm{GC}^{12} \mathrm{GGGCTCCC}{ }^{13}$ GAGC ${ }^{14} \mathrm{GGTTCCA}-\mathrm{AGCC}$ T (2690) CTGTCACCC ${ }^{29} \mathrm{GC}$ AGGGGGACTGGC GGC

Rat

Human

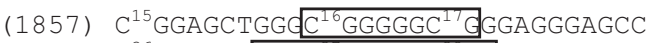
hGR exon $1 \mathrm{~F}$ (2690) $\mathrm{C}^{36}$ GGAGC 7 GGGC $^{3 /}$ GGGGGC $^{38}$ GG GAAGGAGGT 
Figure 4; miRNA target prediction on GR exon 1-C1

PITA
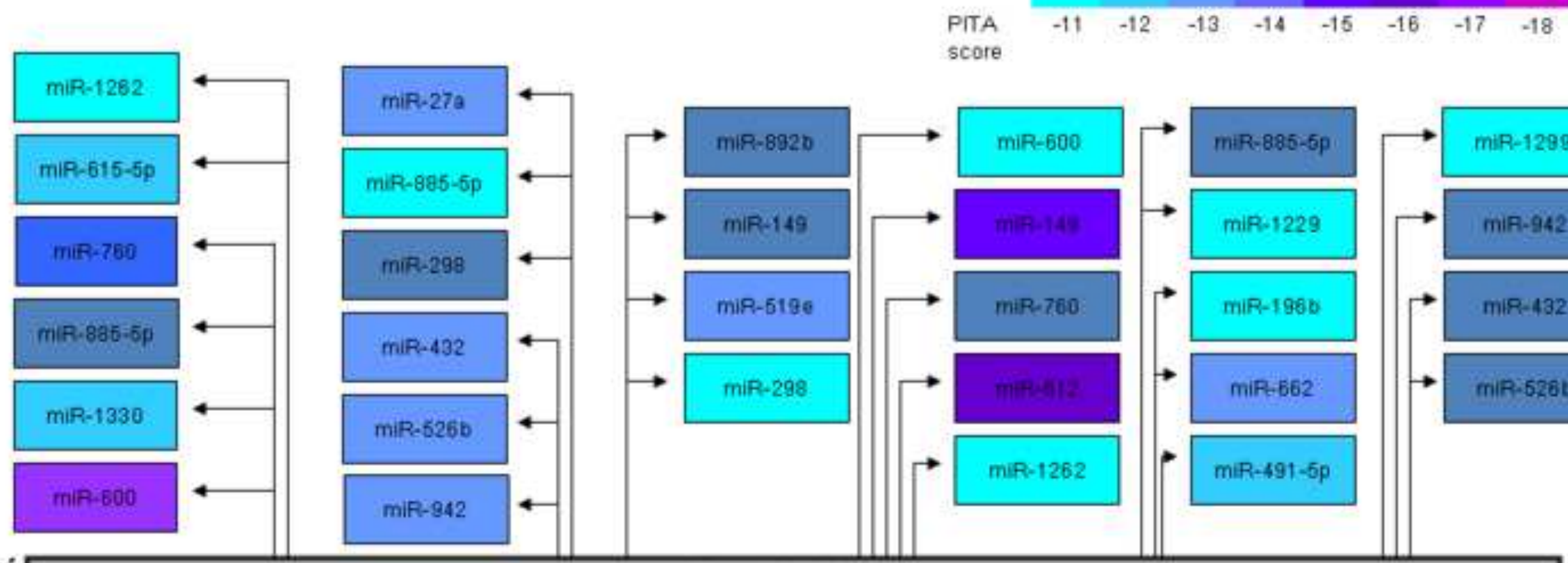

score

5
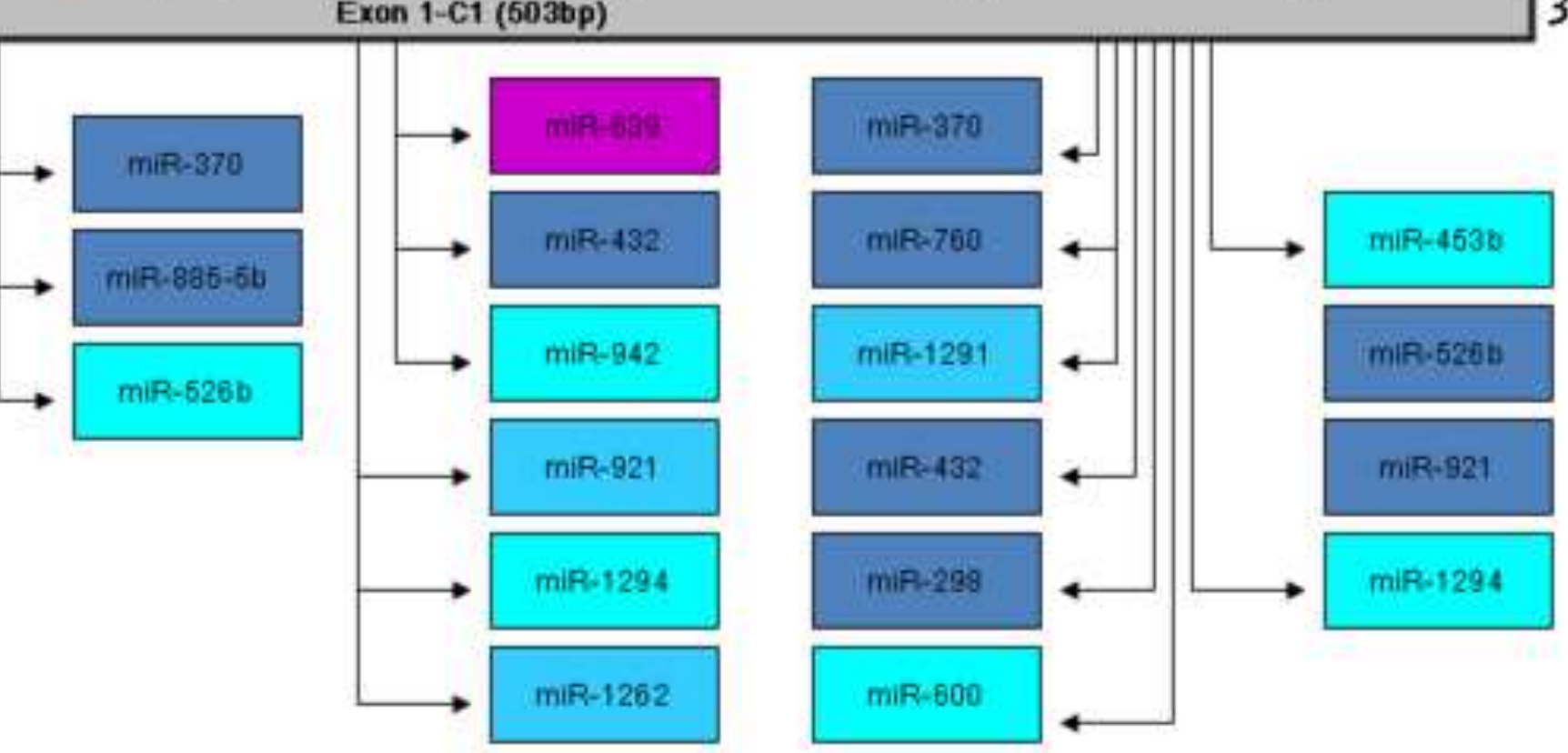

rage 31 or 32 
Glucocorticoid receptor levels are transcriptionally controlled. The variable 5' region produces multiple splice variants coding a single protein, and is regulated by epigenetic methylation and tissue specific transcription factor usage.
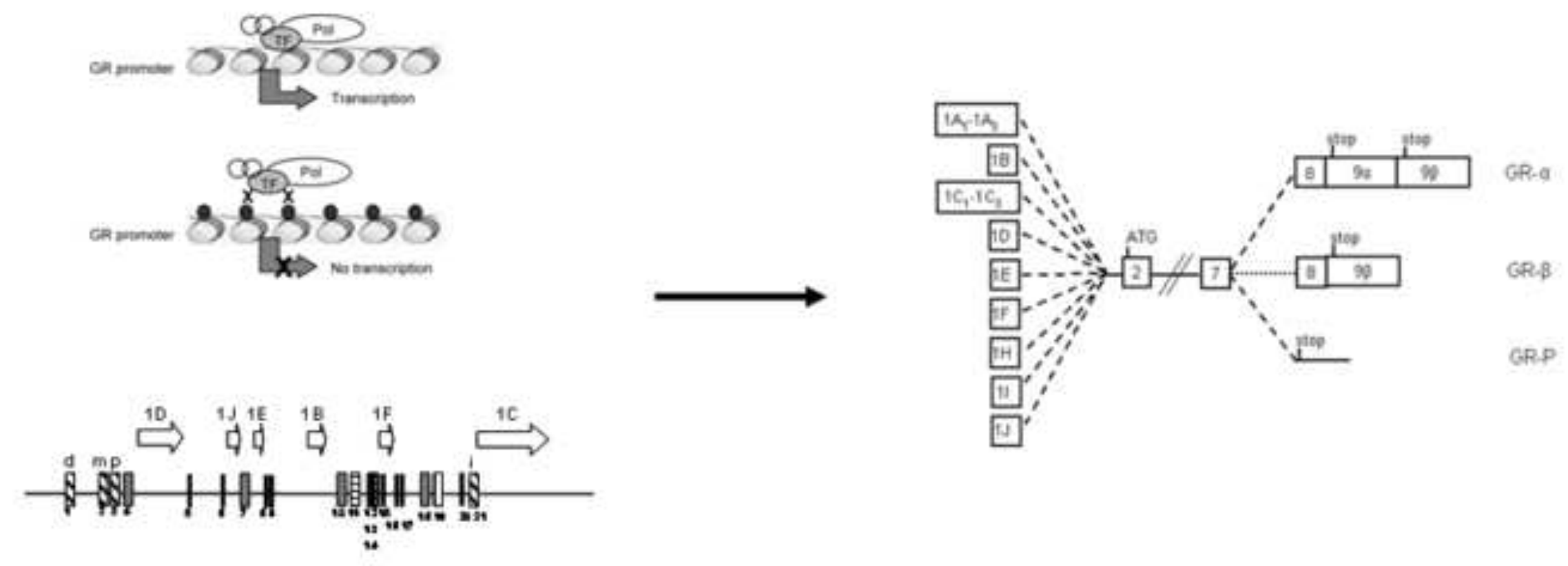